\title{
Potensi budidaya ikan di Waduk Embung Klamalu Kabupaten Sorong Provinsi Papua Barat: Kajian kualitas fisika kimia air
}

\section{(Aquaculture potential in reservoir Embung Klamalu Sorong, West Papua: Study on water physical-chemical quality)}

\author{
Agustina Frasawi, Robert Rompas, Juliaan Watung
}

\begin{abstract}
The objective of this research was to measure and analyze the water quality parameters including temperature, brightness, $\mathrm{pH}$, dissolved oxygen, total alkalinity, carbon dioxide and BOD in reservoir Embung Klamalu Sorong regency, and to know the factors that affected the water quality of Embung Klamalu. Measurement of water quality parameters was done in situ for temperature, brightness, $\mathrm{pH}$ and in laboratory for dissolved oxygen, total alkalinity, carbon dioxide, and BOD. The results showed the temperature at the five observation stations ranged from 26.2 to 29.8 0C, brightness 38 to $46 \mathrm{~cm}$, pH 7.20 to $8.48 \mathrm{mg} / \mathrm{L}$, dissolved oxygen from 7.20 to $8.48 \mathrm{mg} / \mathrm{L}$, alkalinity 100 to $150 \mathrm{mg} / \mathrm{L}$, carbon dioxide from 25.90 to $28.95 \mathrm{mg} / \mathrm{L}$, BOD from 0.20 to 0.38 . Refers to the standards of water quality according to the PP. 82, 2001, it could be concluded that water physical-chemical qualities in fish farming locations in the Village Klamalu were still in good condition.
\end{abstract}

Keywords: Water physical-chemical quality, aquaculture, waduk Embung Klamalu

\section{PENDAHULUAN}

Air merupakan salah satu kebutuhan yang sangat dibutuhkan oleh makhluk hidup yaitu manusia, tumbuhan, hewan yang sangat penting diperlukan untuk memenuhi kebutuhan sehari hari yaitu air bersih dan untuk pembudidayaan ikan membutuhkan kualitas air bersih dan bebas dari pencemaran. Waduk merupakan salah satu contoh perairan tawar buatan yang dibuat dengan cara membendung sungai tertentu dengan berbagai tujuan yaitu sebagai pencegah banjir, pembangkit tenaga listrik, pensuplai air bagi kebutuhan irigasi pertanian, untuk kegiatan perikanan baik perikanan tangkap maupun budidaya karamba, dan bahkan untuk kegiatan pariwisata. (Nastiti, 2001).

Potensi perikanan budidaya di Kabupaten Sorong cukup besar, dimana memiliki sumberdaya alam yang sangat mendukung untuk pengembangan ikan budidaya, salah satu sebagai penghasil ikan budidaya air tawar adalah waduk Embung Klamalu. Jenis budidaya ikan yang dikembangkan sangat beragam yaitu ikan mas, ikan nila, ikan mujair, ikan bawal, ikan gurami, ikan lele dan ikan patin. Untuk tumbuh optimal, biota budidaya membutuhkan lingkungan hidup yang optimal pula. Kualitas air dapat diketahui dari pengukuran parameter untuk budidaya biota 
air yaitu karakteristik fisik dan kimia air. Waduk Embung Klamalu merupakan waduk terbesar di Kabupaten Sorong, luas 125 hektar disebut sebagai waduk mikro atau embung dan dikenal sebagai Embung Klamalu. Lingkungan waduk Embung Klamalu dari tahun ketahun daya dukungnya semakin menurun. Fakta ini didukung oleh beberapa masalah yang teridentifikasi sebagai berikut: kegiatan penambangan galian $\mathrm{C}$, terjadi pendangkalan waduk, melimpahnya tumbuhan air, melimpahnya sampah didalam air. Resultan dari semua masalah ini dapat mempengaruhi keberadaan ikan-ikan yang hidup di waduk (Dinas Kelautan dan Perikanan Kabupaten Sorong, 2012).

Berdasarkan uraian diatas maka timbul gagasan untuk mengadakan penelitian tentang Potensi Budidaya Ikan di waduk Embung Klamalu Kabupaten Sorong Provinsi Papua Barat: Kajian Kualitas Fisika Kimia Air, dengan mengacu kepada Peraturan Pemerintah No. 82 Tahun 2001 tentang Pengelolaan Kualitas Air dan Pengendalian Pencemaran Air. Tujuan Penelitian adalah Untuk mengukur dan menganalisis parameter kualitas air yang meliputi: suhu, kecerahan, pH (derajat keasaman), DO (oksigen terlarut), alkalinitas total, karbondioksida $\left(\mathrm{CO}_{2}\right)$ dan BOD (biochemical oxygen demand), pada lokasi waduk Embung Klamalu, Kabupaten Sorong Provinsi Papua Barat, serta mengetahui faktor kegiatan yang mempengaruhi kondisi kualitas air waduk Embung Klamalu.

\section{BAHAN DAN METODE}

\section{Tempat dan Waktu Penelitian}

Penelitian ini dilakukan pada lokasi budidaya ikan di waduk Embung Klamalu Distrik Aimas Kabupaten Sorong, Provinsi Papua Barat. Penelitian ini dilakukan pada bulan November 2012 - Desember 2012.

\section{Teknik Pengambilan Sampel}

Pengambilan sampel dilakukan dengan menggunakan metode purposif yaitu pada 5 titik yang telah ditentukan berdasarkan pada aktivitas lokasi waduk di Desa Embung Klamalu, Distrik Aimas Kabupaten Sorong.

Pengambilan air sampel dilakukan pada lima titik, pengamatan titik didasarkan pada: titik 1. sumber air (inlet), Titik 2. saluran pengeluaran air (Outlet), titik 3. galian batu, titik 4. pabrik pembuatan batubata, titik, 5 . pemukiman. Pengambilan dan pengukuran sampel air dilakukan dua kali dengan interval waktu satu minggu yaitu pada pagi dan sore hari dimana suhu, kecerahan, $\mathrm{pH}$, dan DO pengukuran dilaksanakan langsug dilapangan, sedangkan untuk alkalinitas total, karbondioksida, BOD dianalisis di Laboratorium Kelautan dan Perikanan Akademi Perikanan Sorong.

Sampel yang diambil dari tiap titik sampel kemudian dimasukan ke dalam kotak pendingin (cool box) kemudian dibawa ke laboratorium untuk dianalisis. Sampel dibawa kelaboratorium tidak lebih dari 24 jam di dalam pendingin untuk menjaga kestabilan dan kualitas air sampel.

\section{Cara Kerja Penelitian}

Penelitian dilakukan dengan dua cara yaitu pengukuran in situ meliputi Suhu, Kecerahan, pH, DO, analisis laboratorium meliputi Alkalinitas total, karbondioksida dan BOD. Data yang diperoleh dalam penelitian di bandingkan dengan bakumutu air untuk kegiatan perikanan berdasarkan standar bakumutu PP. No. 82 Tahun 2001 (kelas II), tentang Pengelolaan Kualitas Air Dan Pengendalian Pencemaran Air.

\section{Pengumpulan dan Analisis Data}

Pengukuran parameter kualitas air dilakukan dengan dua cara yaitu in situ untuk suhu dengan thermometer, kecerahan dengan Sechii disk, $\mathrm{pH}$ dengan $\mathrm{pH}$ meter, dan (DO) 
dengan DO meter dan analisis laboratorium untuk alkalinitas, karbondioksida, dan BOD. Sampel yang diambil dari tiap titik dimasukan ke dalam botol sampel dan dimasukan kedalam coll box yang berisikan es. Kemudian botol sampel dibawa ke Laboratorium Lingkungan dan Kualitas Air Akademi Perikanan Sorong untuk dianalisis.

Data yang diperoleh dalam penelitian dibuat tabulasi grafik kemudian di bandingkan dengan bakumutu air untuk kegiatan perikanan berdasarkan standar bakumutu PP. No. 82 Tahun 2001 (kelas II), tentang Pengelolaan Kualitas Air Dan Pengendalian Pencemaran Air.

\section{HASIL DAN PEMBAHASAN}

Perbandingan hasil pengukuran dilapangan dan analisis laboratorium menurut standar bakumutu PP No. 82 Tahun 2001 (kelas II), tentang Pengelolaan Kualitas Air Dan Pengendalian Pencemaran Air. dan kondisi perairan yang baik utuk meunjang kegiatan budidaya ikan air tawar berdasarkan literatur, dapat di lihat pada tabel 1 .

\section{a. Parameter Fisika}

\section{Suhu}

Data hasil pengukuran suhu pada titik I, II, III, IV dan V, pada waktu pagi dan sore ditampilkan pada gambar 1 .

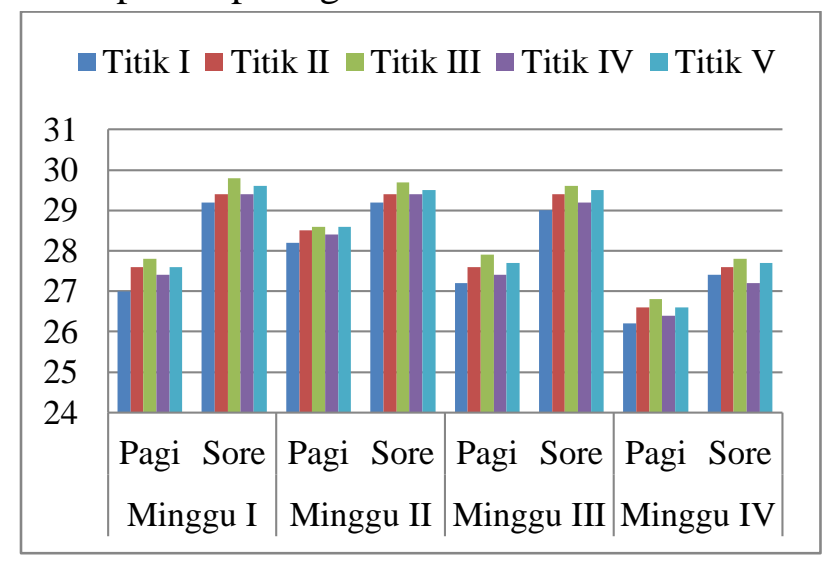

Gambar 1. Suhu air di Waduk Embung Kamalu
Menurut standar bakumutu PP No. 82 Tahun 2001 (kelas II), tentang Pengelolaan Kualitas Air Dan Pengendalian Pencemaran Air.), kisaran suhu untuk kegiatan budidaya ikan air tawar adalah deviasi 3 sedangkan toleransi suhu perairan yang baik untuk menunjang pertumbuhan optimal dari beberapa ikan budidaya air tawar seperti mas dan nila adalah $28{ }^{0} \mathrm{C}$. Hasil pengukuran dilapangan, suhu tertinggi berada di titik 3 minggu pertama pada waktu sore dengan nilai 29,8 ${ }^{\circ} \mathrm{C}$ dan suhu terendah berada di titik 1 minggu keempat pada waktu pagi yaitu $26,2{ }^{0} \mathrm{C}$.

Suhu mempunyai peranan penting dalam menentukan pertumbuhan ikan yang dibudidaya, kisaran yang baik untuk menunjang pertumbuhan optimal adalah $28{ }^{0} \mathrm{C}-32{ }^{0} \mathrm{C}$. Hal ini menunjukkan bahwa keadaan suhu air dilokasi waduk Embung Klamalu masih layak dan memenuhi syarat untuk pengembangan usaha budidaya ikan.

\section{Kecerahan}

Data hasil pengukuran kecerahan pada titik I, II, III, IV dan V, pada waktu pagi dan sore ditampilkan dalam bentuk histogram berikut.

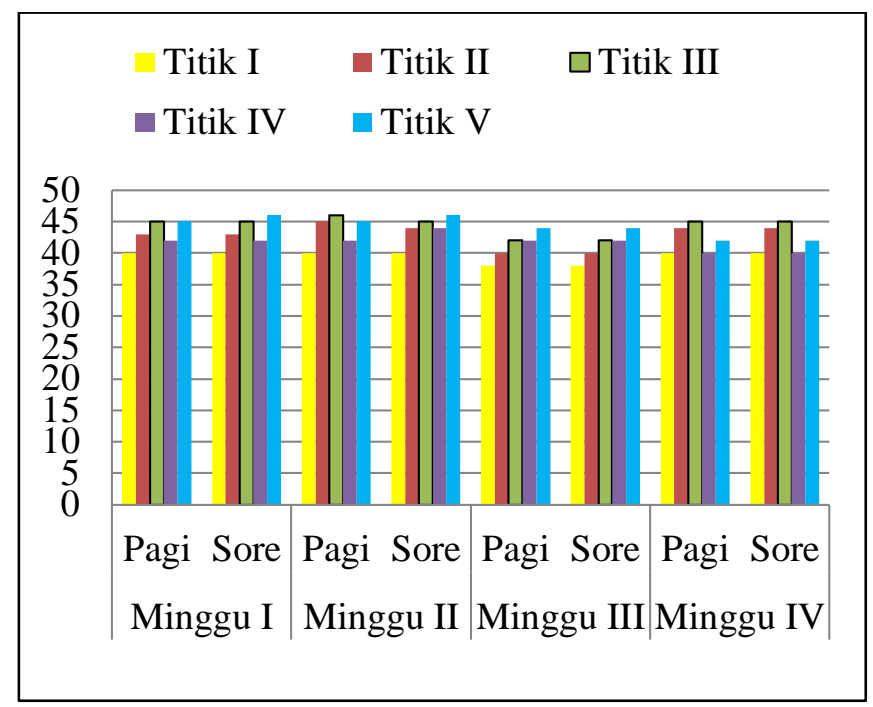

Gambar 2. Kecerahan air 
Hasil pengukuran dilapangan pada lima titik pengamatan diperoleh nilai kecerahan tertinggi pada pengukuran minggu pertama dan minggu kedua titik 3 dan titik 5 pada waktu siang yaitu kecerahan $46 \mathrm{~cm}$ dan nilai kecerahan terendah terdapat pada pengukuran minggu ketiga titik 1 waktu pagi yaitu 38 cm. Menurut Pescod (1973) merupakan suatu kondisi yang menggambarkan suatu kemampuan penetrasi cahaya matahari untuk menembus permukaan air sampai kedalaman tertentu. Besarnya kecerahan suatu perairan sangat tergantung pada warna air dan kekeruhan, dalam hal ini semakin gelap warnanya akan semakin keruh, maka kecerahannya semakin rendah. Menurut Boyd (1982) kisaran kecerahan perairan untuk air tawar 25 - $40 \mathrm{~cm}$. Secara umum kecerahan di lokasi penelitian berada dalam kondisi alami karena perairan dengan tingkat kecerahan 25 - $40 \mathrm{~cm}$ sangat baik untuk budidaya ikan.

\section{b. Parameter Kimia}

\section{pH (derajat keasaman)}

Data hasil pengukuran $\mathrm{pH}$ pada titik I, II, III, IV dan V, pada waktu pagi dan sore ditampilkan dalam bentuk histogram.

Gambar 4 .

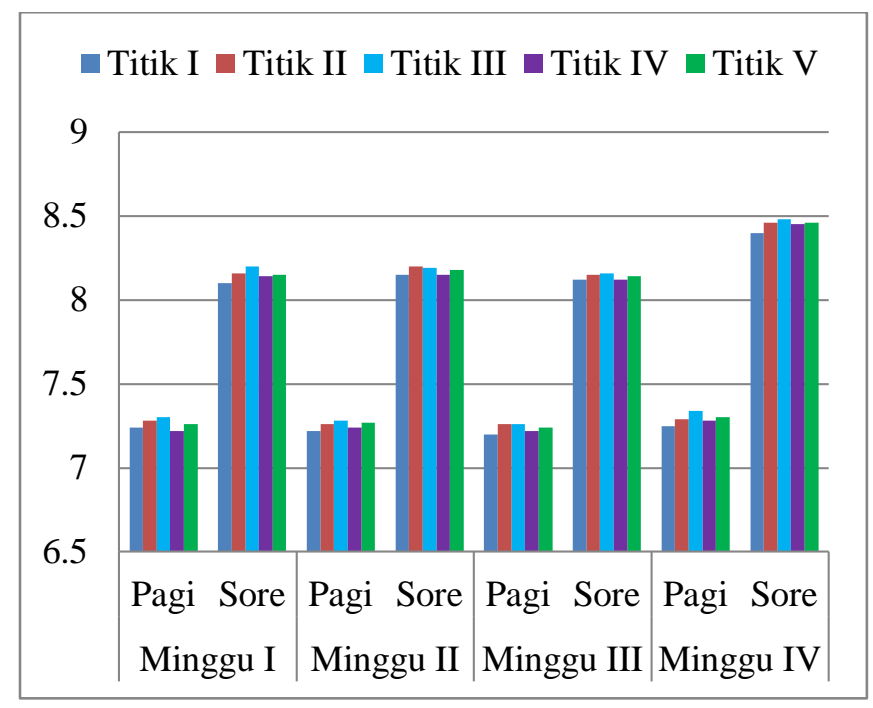

Gambar 3. pH air pada lokasi penelitian
Hasil pengukuran $\mathrm{pH}$ di titik I, II, III, IV dan $\mathrm{V}$ pengamatan pada sore $\mathrm{pH}$ tertinggi berada pada minggu keempat titik 3 dengan nilai 8,48 sedangkan $\mathrm{pH}$ terendah terdapat pada minggu ketiga titik 1 dengan nilai 7,20. Berdasarkan standart bakumutu PP No. 82 Tahun 2001 (kelas II), menyatakan $\mathrm{pH}$ yang baik untuk kegiatan budidaya ikan air tawar berkisar antara 6 - 9. Hal ini menunjukkan bahwa $\mathrm{pH}$ di lokasi waduk Embug Klamalu berada dalam batas alami dan layak untuk dilakukan kegiatan usaha budidaya karena pH berada pada kisaran 7,20 - 8,48. pH yang ideal bagi kehidupan biota air tawar menurut Boyd (1979) adalah antara 6,8 - 8,5. Apabila pH yang sangat rendah, menyebabkan kelarutan logam-logam dalam air makin besar, akan bersifat toksik bagi organisme air, sebaliknya $\mathrm{pH}$ yang tinggi dapat meningkatkan kosentrasi amoniak dalam air yang juga bersifat toksik bagi organisme air.

\section{DO (oksigen terlarut)}

Data hasil pengukuran DO (oksigen terlarut) pada titik I, II, III, IV dan V, pada waktu pagi dan sore ditampilkan dalam bentuk histogram.

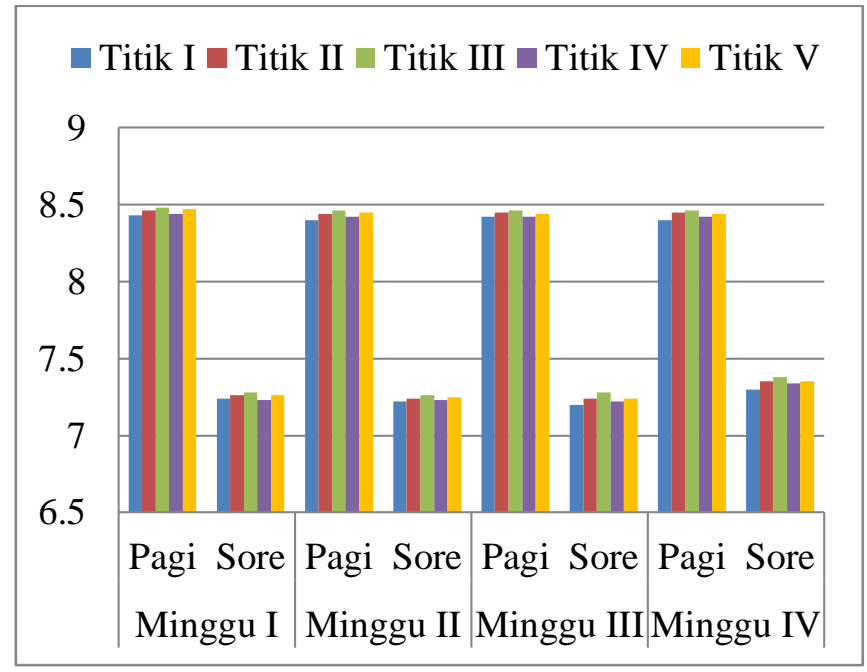

Gambar 4. Oksigen Terlarut pada lokasi penelitian

Berdasarkan standar bakumutu PP No. 82 Tahun 2001 (kelas II), tentang Pengelolaan 
Kualitas Air Dan Pengendalian Pencemaran Air. kisaran oksigen terlarut untuk kegiatan budidaya ikan yaitu > $4 \mathrm{mg} / \mathrm{l}$. Hasil pengukuran dilapangan pada lima titik pengamatan, DO tertinggi berada pada minggu pertama titik 3 dengan nilai 8,48 $\mathrm{mg} / \mathrm{L}$, sedangkan DO terendah terdapat pada minggu ketiga titik 1 dengan nilai 7,20 mg/L . Menunjukkan bahwa secara keseluruhan nilai parameter DO pada lima titik pengamatan dengan kisaran nilai 7,20-8,48 mg/L, menurut Boyd (1979) menyatakan bahwa $\mathrm{DO}>5 \mathrm{mg} / \mathrm{L}$ sangat baik untuk kelangsungan kegiatan budidaya ikan, sebab hasil yang didapatkan dalam penelitian masih berada diatas baku mutu kualitas air yang ditetapkan untuk kegiatan ikan air tawar menurut standar bakumutu PP No. 82 Tahun 2001 (kelas II), yaitu $>4 \mathrm{mg} / \mathrm{L}$.

\section{Alkalinitas Total}

Data hasil pengukura Alkalinitas Total pada titik I, II, III, IV dan V, pada waktu pagi dan sore ditampilkan dalam bentuk histogram.

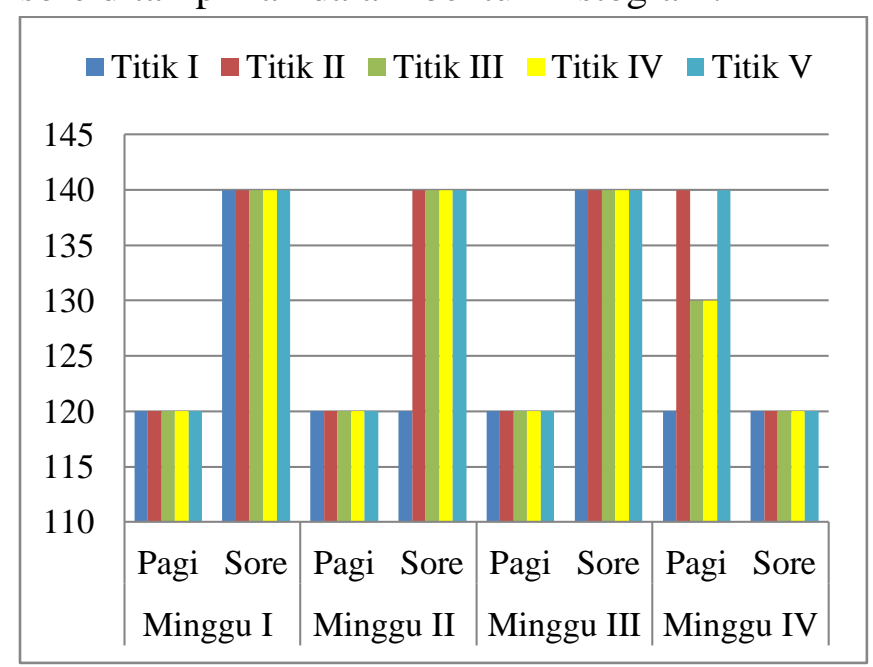

Gambar 5. Alkalinitas Total

Hasil pengukuran Alkalinitas Total di titik I, II, III, IV dan V pengamatan pada sore , alkalinitas total tertinggi berada pada minggu pertama minggu kedua dan minggu keempat titik 3 dengan nilai $150 \mathrm{mg} / \mathrm{L}$, sedangkan alkalinitas total terendah terdapat pada minggu kesatu minggu ketiga dan minggu keempat titik 1 dengan nilai 100 mg/L. Berdasarkan standar bakumutu PP No. 82 Tahun 2001 (kelas II), tentang Pengelolaan Kualitas Air Dan Pengendalian Pencemaran Air, menyatakan alkalinitas total yang baik untuk kegiatan budidaya ikan air tawar 30 - 500 mg/L. Menurut Effendi (2003), alkalinitas alami tidak pernah melebihi 500 mg/L. Perairan dengan nilai alkalinitas yang terlalu tinggi tidak disukai oleh organisme akuatik karena biasanya diikuti dengan nilai kesadahan yang tinggi atau kadar garam natrium yang tinggi. Hal ini menunjukkan bahwa alkalinitas total di lokasi penelitian masih berada dalam batas alami dan masih layak untuk dilakukan kegiatan usaha budidaya karena alkalinitas total berada pada kisaran 100 - 150 mg/L.

\section{Karbondioksida $\left(\mathrm{CO}_{2}\right)$}

Data hasil pengukuran Karbondioksida $\left(\mathrm{CO}_{2}\right)$ pada titik I, II, III, IV dan V, pada waktu pagi dan sore ditampilkan dalam bentuk histogram.

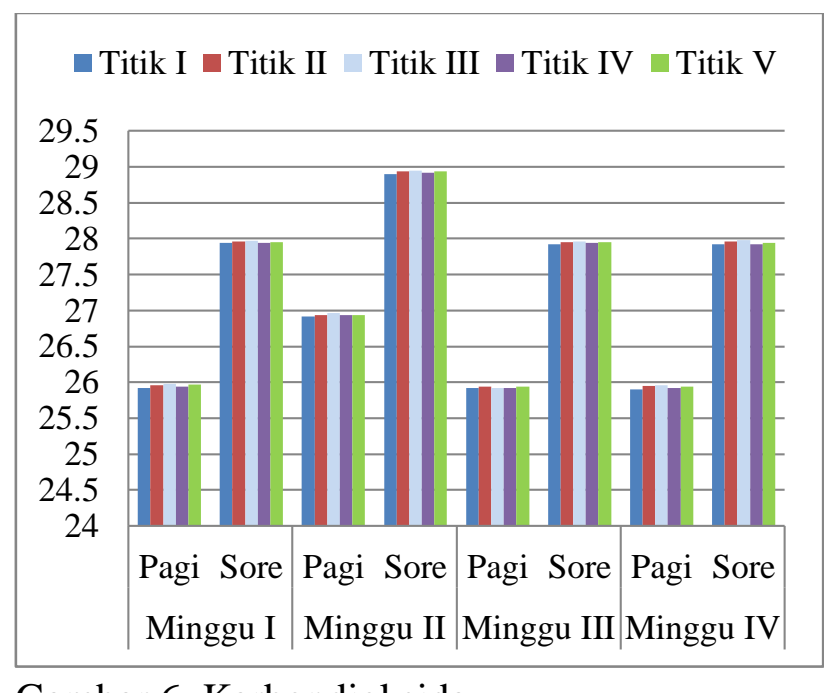

Gambar 6. Karbondioksida

Hasil pengukuran pada lima titik pengamatan, karbondioksida $\left(\mathrm{CO}_{2}\right)$ tertinggi berada pada minggu kedua minggu titik 3 dengan nilai 28,95 mg/L, sedangkan karbondioksida 
$\left(\mathrm{CO}_{2}\right)$ terendah terdapat pada minggu keempat titik 1 dengan nilai 25,90 mg/L. Hasil diatas jika dibandingkan dengan standar bakumutu PP No. 82 Tahun 2001 (kelas II), tentang Pengelolaan Kualitas Air Dan Pengendalian Pencemaran Air, batas maksimum karbondioksida untuk kegiatan budidaya air tawar 2 - $9 \mathrm{mg} / \mathrm{L}$. Menurut (M. Ghufran dan Kordi, 2007) pada umumnya perairan alami mengandung karbondioksida sebesar $2 \mathrm{mg} / \mathrm{l}$. Pada kosentrasi yang tinggi (> 10 mg/l), karbondioksida dapat beracun, karena keberadaannya dalam darah dapat menghambat pengikatan oksigen oleh hemoglobin. Hal ini menunjukkan bahwa karbondioksida $\left(\mathrm{CO}_{2}\right)$ di lokasi penelitian masih berada dalam batas alami dan masih layak untuk dilakukan kegiatan usaha budidaya karena karbondioksida $\left(\mathrm{CO}_{2}\right)$ berada pada kisaran 25,90 -28,95 mg/L.

\section{BOD (biological oxygen demand)}

Data hasil pengukuran BOD pada titik I, II, III, IV dan V, pada waktu pagi dan sore ditampilkan dalam bentuk histogram.

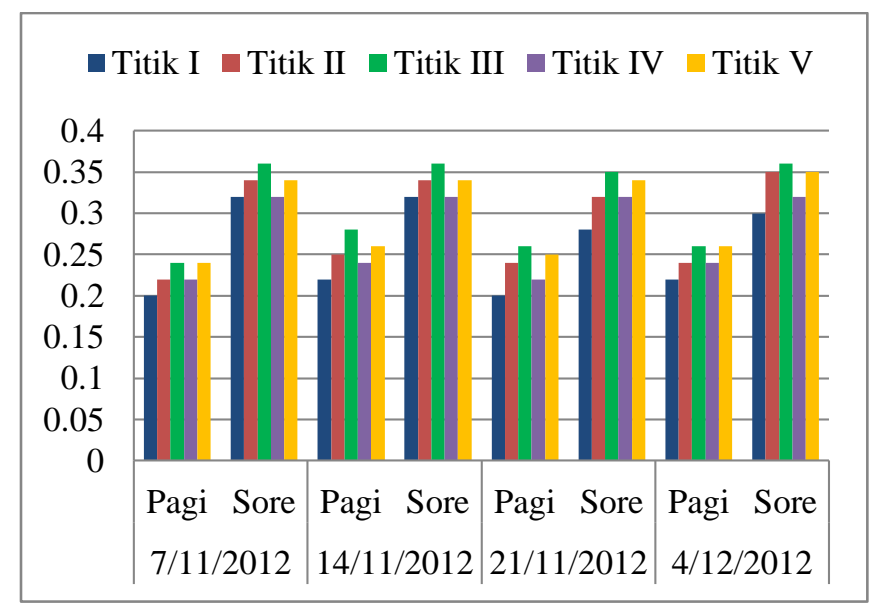

Gambar 7. BOD pada lokasi penelitian
Hasil pengukuran BOD 5 titik pengamatan pada waktu pagi dan sore terdapat pada gambar 8 dan ditampilkan dalam bentuk histogram. Untuk analisis laboratorium digunakan BOD 5. Penentuan waktu 5 hari, dapat mengurangi kemungkinan hasil oksidasi amoniak $\left(\mathrm{NH}_{3}\right)$ yang cukup tinggi. Sebagaimana diketahui bahwa amoniak sebagai hasil sampingan ini dapat dioksidasi menjadi nitrit dan nitrat, sehingga dapat mempengaruhi hasil penentuan BOD. Selama 5 hari masa inkubasi, diperkirakan 70\% - 80\% bahan organik telah mengalami oksidasi.

Berdasarkan Hasil yang diperoleh dari 5 titik pengamatan, maka nilai BOD tertinggi berada pada minggu pertama dan minggu kedua titik 3 dengan nilai 0,36 mg/L, sedangkan BOD terendah terdapat pada minggu pertama dan minggu ketiga titik 1 yaitu 0,20 mg/L. Menurut standar bakumutu PP No. 82 Tahun 2001 (kelas II), tentang Pengelolaan Kualitas Air Dan Pengendalian Pencemaran Air. nilai BOD untuk kegiatan budidaya $>3 \mathrm{mg} / \mathrm{L}$, hal ini menunjukkan bahwa parameter BOD di lokasi penelitian sangat baik secara keseluruhan nilai parameter BOD pada lima titik pengamatan dengan kisaran nilai 0,20 - 0,36 mg/L, menurut Zonneveld (1991), menyatakan bahwa kandungan BOD dalam suatu perairan untuk ikan air tawar $6 \mathrm{mg} / \mathrm{L}$, baik untuk kelangsungan kegiatan budidaya ikan, sebab hasil yang didapatkan dalam penelitian masih berada diatas baku mutu kualitas air yang ditetapkan untuk kegiatan ikan air tawar menurut standar bakumutu PP No. 82 Tahun 2001 (kelas II),) yaitu $>3 \mathrm{mg} / \mathrm{L}$. 
Tabel 1. Perbandingan kisaran nilai kualitas air menurut standar baku mutu kualitas air sesuai Peraturan Pemerintah No. 82 Tahun 2001

\begin{tabular}{|c|c|c|c|c|}
\hline $\mathrm{N}$ & $\begin{array}{c}\text { Parameter/ } \\
\text { satuan }\end{array}$ & $\begin{array}{c}\text { Hasil } \\
\text { Pengukuran }\end{array}$ & $\begin{array}{l}\text { Standar Baku mutu PP No. } 82 \text { Tahun } \\
2001 \text { untuk kegiatan budidaya ikan air } \\
\text { tawar (kelas II) }\end{array}$ & $\begin{array}{l}\text { Perairan yang baik untuk } \\
\text { menunjang kegiatan } \\
\text { budidaya ikan air tawar }\end{array}$ \\
\hline \multicolumn{5}{|c|}{ Fisika } \\
\hline 1 & Suhu & $26,2{ }^{0} \mathrm{C}-29,8{ }^{0} \mathrm{C}$ & Deviasi 3 & $28{ }^{0} \mathrm{C}-32{ }^{0} \mathrm{C}$ \\
\hline 2 & Kecerahan & $38-46 \mathrm{~cm}$ & & $2 \mathrm{~m}$ \\
\hline \multicolumn{5}{|c|}{ Kimia } \\
\hline 3 & $\mathrm{pH}$ & $7,20-8,48$ & $6-9$ & $6,8-8,5$ \\
\hline 4 & DO & $7,22-8,48 \mathrm{mg} / \mathrm{L}$ & $4 \mathrm{mg} / \mathrm{L}$ & $\geq 5 \mathrm{mg} / \mathrm{L}$ \\
\hline 5 & Alkalinitas & $100-150 \mathrm{mg} / \mathrm{L}$ & $30-500 \mathrm{mg} / \mathrm{L}$ & $30-500 \mathrm{mg} / \mathrm{L}$ \\
\hline 6 & Karbondioksida & $25,90-28,95 \mathrm{mg} / \mathrm{I}$ & $2-9 \mathrm{mg} / \mathrm{L}$ & $2-9 \mathrm{mg} / \mathrm{L}$ \\
\hline 7 & BOD & $0,20-0,38 \mathrm{mg} / \mathrm{L}$ & $3 \mathrm{mg} / \mathrm{L}$ & $0-10 \mathrm{mg} / \mathrm{L}$ \\
\hline
\end{tabular}

\section{KESIMPULAN}

Parameter kualitas perairan waduk Embung Klamalu yang meliputi suhu, kecerahan, pH (derajat keasaman), DO (oksigen terlarut), alkalinitas, karbondioksida $\left(\mathrm{CO}_{2}\right)$, BOD, masih berada dalam kondisi yang layak untuk pertumbuhan ikan dengan mengacu pada standar bakumutu PP No. 82 Tahun 2001 (kelas II), tentang Pengelolaan Kualitas Air Dan Pengendalian Pencemaran Air.

\section{DAFTAR PUSTAKA}

Baku Mutu, 2001. Peraturan Pemerintah No. 82 Tentang Pengelolaan Kualitas Dan Pengendalian Pencemaran Air.

Boyd CE, F. Lichkopper, 1979. Water Quality Managemen in Pont Fish culture. Aubum Univercity Agricultural Experimental Station. Alabama.

Boyd CE, F. Lichkopper, 1982. Water Quality management For Pond Fish culture. Elsevier Scientific Publishing Company Amsterdam New York.

Dinas Perikanan dan Kelautan Kabupaten Sorong, 2012. Laporan Akuntabilitas Instansi Pemerintah (LAKIP). Kabupaten Sorong.
Effendy H, 2003. Telaah Kualitas Air Bagi Pengelolaan Sumberdaya dan Lingkungan Perairan. 259 hal.

M. Ghufran, Tanjung AB, 2007. Pengelolaan Kualitas Air Dalam Budidaya Perairan, Rineka Cipta. Jakarta

Nastiti, 2001. Daya Dukung Perairan Waduk Jatiluhur untuk Budidaya Ikan Dalam Karamba Jaring Apung. Jurnal Penelitian Perikanan Indonesia. Volume 7. Hal 15-19.

Pescod MB, 1992. Investigation Of Rational Effluent and Stream Standards For Tropical Countries. US Army Research and Development Group Far Eas. PO San Fransisco. AIT Bangkok. 59

Zonneveld, C. 1991. Estimating death rates from transect. Ecological Entomologi 16 (1) : 115-121. 